\title{
TACTICAL APPLICATION OF FERTILIZER NITROGEN TO OFFSET A SEASONAL FEED SHORTAGE ON A HEAVILY STOCKED SHEEP FARM IN SOUTHERN HAWKE'S BAY
}

\author{
i) Roger Ball,* J. A. H. Inglis $\dagger$ and J. H. Mauger $\ddagger$
}

\section{Abstract}

An experiment was conducted within the confines of a practical farming situation. Two treatments were compared: "Control", where the normal stocking rate was imposed without fertilizer nitrogen, and "Nitrogen", where a single dressing of urea was combined with a $10 \%$ increase in the normal stocking rate. Urea was applied when ewes were set-stocked for lambing, in late winter 1970. Pasture production and animal liveweights were recorded over the ensuing three to four months.

Measurements under cage exclosures in the grazed paddocks indicated an overall yield response of $1820 \mathrm{~kg} \mathrm{DM} / \mathrm{ha}(+36 \%)$ to the single dressing of $58 \mathrm{~kg} \mathrm{~N} / \mathrm{ha}$. A greater response was recorded from grasses other than ryegrass, than from ryegrass, which constituted $50 \%$ of control yield. The $\mathrm{N}$ effect declined with time. Responses occurred irrespective of aspect or slope. Similar measurements under cages, where herbage was repeatedly cut and discarded, indicated a smaller response and failed to show residual effects of $\mathrm{N}$.

Ewe liveweights showed a greater increase in the Nitrogen group, and lamb liveweights were almost identical between treatments These results indicate that urea application stimulated pasture growth sufficiently to more than meet the requirements of the additional stock.

\section{INTRODUCTION}

THERE has been little research into the use of fertilizer nitrogen in New Zealand hill country farming. Sherlock and O'Connor (1973) recently reported pasture responses to applied $\mathrm{N}$ during 1971 and 1972, measured in mowing trials at Te Kuiti. They considered their data supported a case for fertilizer $\mathrm{N}$ use in hill country beef operations throughout the King Country area, at costs and prices ruling during 1973, but considered the use of fertilizer $N$ in sheepfarming as "a matter for hypothesis". There appears to be no research report relating to $\mathrm{N}$ use under sheepfarming conditions in New Zealand.

* Grasslands Division, DSIR, Palmerston North.

† Farmer, "Ratahiwi", R.D. 2, Woodville.

$\ddagger$ East Coast Farmers’ Fertilizer Co., Dannevirke. 
TABLE 1: SITE DESCRIPTION OF PADDOCKS INVOLVED AND STOCKING RATES. (S.R.)

\begin{tabular}{|c|c|c|c|c|c|}
\hline \multicolumn{2}{|c|}{$\begin{array}{l}\text { Blocks and } \\
\text { Treatments }\end{array}$} & Site Description and Soil Characteristics* & \multirow{2}{*}{$\begin{array}{c}\begin{array}{c}\text { Area } \\
(\text { ha })\end{array} \\
9.72\end{array}$} & \multirow{2}{*}{$\begin{array}{r}\text { Mob } \\
\text { Size } \\
150\end{array}$} & \multirow{2}{*}{$\begin{array}{c}\begin{array}{c}S . R . \\
\text { (ewes/ha) }\end{array} \\
15.4\end{array}$} \\
\hline I & Control & $\begin{array}{l}\text { Rolling, steep faces, W. aspect, } 230 \mathrm{~m} \text { a.s.l. } \\
\text { Gleyed intergrades Y.G.E.-Y.B.E. }\end{array}$ & & & \\
\hline & Nitrogen & $\begin{array}{l}\text { Makotuku hill soil-Matamau si. } 1 . \\
\text { pH 5.3, Ca 7, K 15, P } 11\end{array}$ & 10.93 & 175 & 16.0 \\
\hline \multirow[t]{2}{*}{ II } & Control & $\begin{array}{l}\text { Rolling, steep faces, small flat areas, } \\
\text { W. aspect, } 210 \mathrm{~m} \text { a.s.l. }\end{array}$ & 6.58 & 85 & 13.1 \\
\hline & Nitrogen & $\begin{array}{l}\text { Soils as in I } \\
\text { pH } 5.3, \text { Ca } 7, \mathrm{~K} 14, \mathrm{P} 8\end{array}$ & 9.31 & 150 & 10.1 \\
\hline \multirow[t]{2}{*}{ III } & Control & $\begin{array}{l}\text { Easy rolling, E. aspect, } 180 \mathrm{~m} \text { a.s.1. } \\
\text { Intergrades Y.B.E.-Y.B.L. }\end{array}$ & 4.45 & 62 & 13.9 \\
\hline & Nitrogen & $\begin{array}{l}\text { Predominantly Dannevirke si. } 1 . \\
\text { pH 5.5, Ca } 8, \mathrm{~K} 12, \mathrm{P} 7\end{array}$ & 4.86 & 70 & 14.4 \\
\hline \multirow[t]{2}{*}{ IV } & Control & $\begin{array}{l}\text { Rolling, steep faces, N. aspect } \\
200 \text { m a.s.1. }\end{array}$ & 5.59 & 110 & 19.7 \\
\hline & Nitrogen & $\begin{array}{l}\text { Soils as in I } \\
\mathrm{pH} 5.3 \text {, Ca } 7, \mathrm{~K} 13, \mathrm{P} 11\end{array}$ & 4.17 & 89 & 18.7 \\
\hline \multirow[t]{2}{*}{$\mathrm{v}$} & Control & $\begin{array}{l}\text { Relatively flat, W. aspect, } 180 \mathrm{~m} \text { a.s.l. } \\
\text { Intergrades Y.B.E.-Y.G.E. and Y.B.E.-Y.B.L. }\end{array}$ & 4.45 & 67 & 15.1 \\
\hline & Nitrogen & $\begin{array}{l}\text { Dannevirke si. 1. and Matamau si. } 1 . \\
\text { pH 5.5, Ca 9, K 13, P } 8\end{array}$ & 4.45 & 77 & 17.3 \\
\hline \multirow[t]{2}{*}{ VI } & Control, & Details as in $\mathrm{V}$ & 4.05 & 53 & 13.1 \\
\hline & Nitrogen & $\mathrm{pH} 5.5, \mathrm{Ca} 8, \mathrm{~K} 10, \mathrm{P} 9$ & 4.05 & 67 & 16.5 \\
\hline
\end{tabular}

Average S.R. 15.8 ewes/ha (Control 15.1, Nitrogen 16.5)

* N.Z.M.S. 237/3, Land Inventory Survey, Woodville County, Publ. Dept Lands and Survey 1971.

Soil "quick test" results by courtesy Ministry of Agriculture and Fisheries, Ruakura, Hamilton. 
Late winter-early spring appears to be the period when feed availability causes most general concern to hill country farmers in the lower North Island (Mauger, 1971; Neilson, 1974). While many farmers were convinced of the value of tactical inputs of fertilizer $\mathrm{N}$ over this period, they were making decisions in the virtual absence of relevant measurements. On-farm practices encountered by the writers ranged from land-application to the better, flat areas associated with hill country properties, for intensive beef management, to aerial application of $\mathrm{N}$ to steep hill country, where ewes were set-stocked for lambing. Accordingly, it was decided to obtain some objective measure of the worth, or otherwise, of this practice.

The property of Inglis and Company was made available for this experiment. The owners considered that a recurrent feed shortage during late winter-early spring (late July-early October) was the limiting factor to further intensification of sheepfarming on their property. The experimental objective was to ascertain whether tactical use of fertilizer $\mathrm{N}$ could alleviate this critical period of feed shortage, thereby raising carrying capacity, within any restrictions imposed by existing pastures and management practices.

\section{EXPERIMENTAL}

\section{Treatments and Site}

The farm is situated on the eastern side of the Ruahine Range, some $5 \mathrm{~km}$ due north of Woodville, and ranges in altitude from 150 to $400 \mathrm{~m}$ above sea level. The moist, cool climate gives a long growing season, with annual rainfall in the vicinity of $1350 \mathrm{~mm}$. The property has a history of relatively intensive sheepfarming since it was taken over by the present owners in 1950. Fertilizers, mainly superphosphate at 250 to $315 \mathrm{~kg} / \mathrm{ha}$, had been applied to the whole property each year for the previous 15 years, although none was applied in the year immediately preceding this study. Molybdenum had been included, with apparent advantage. Recent experience with potassic fertilizer had indicated no $\mathrm{K}$ deficiency. The farm supported pastures with a reasonable perennial ryegrass content.

Pairs of paddocks were selected for similarity in soil type, slope, aspect and previous stock carrying capacity. Six pairs were chosen throughout the farm. Two could be described as predominantly flat, two flat to rolling, and two rolling to steep. All experimental paddocks were intensively grazed by mob-stocked ewes within 
7 days of the experiment's commencement. Two treatments were imposed:

(1) Control. In-lamb ewes were set-stocked at the "normal" stocking rate (i.e., the mob size for that paddock, as determined by the owners' experience and records).

(2) Nitrogen. In this treatment, each paddock received $58 \mathrm{~kg}$ $\mathrm{N} /$ ha, and was stocked with in-lamb ewes at its "normal" stocking rate +2.5 ewes/ha.

Treatments were randomly allocated between paddocks within pairs, giving 6 replications. Urea was applied on August 13, 1970, and sheep were introduced to all experimental paddocks within the following two days. Site descriptions, soil characteristics and stocking rates are presented in Table 1. Soils were sampled before commencement of the experiment, and quick-test results are presented. $\mathrm{K}$ tests were relatively high, while $\mathrm{P}$ test figures in the range 7 to 11 indicated medium to good available $\mathrm{P}$ status.

\section{Nitrogen Application}

Prior work indicated that the $\mathrm{N}$ application rate selected, $58 \mathrm{~kg}$ $\mathrm{N} / \mathrm{ha}$, was just above the linear portion of response curves for lower North Island conditions (During, 1967; Ball and Field, unpublished data). Urea was the form of $\mathrm{N}$ chosen because its prilled nature suited aerial application, it is normally cheaper per unit of $\mathrm{N}$ than alternative forms, and because previous research had shown little difference in effectiveness of $\mathrm{N}$ among the forms of fertilizer commercially available (During, 1967; Ball, 1970a) .

Steepness of the terrain and wetness over the late winter-spring period, meant that aerial application was the only feasible method of application. Preliminary test runs were conducted near Dannevirke, to assess swath width and displacement. A "Beaver" (DHC-2) light aircraft was used, flying at an altitude of approximately $15 \mathrm{~m}$. The aircraft was fitted with an Easton (Dannevirke) Air Flow Seed Spreader. At an application rate of $60 \mathrm{~kg}$ urea/ha, granule frequency was fairly uniform over a swath width of $12.5 \mathrm{~m}$, outside of which frequency fell away rapidly. The swath was displaced some $12 \mathrm{~m}$ by a $25 \mathrm{~km} / \mathrm{h}$ (estimated) cross-wind, but spread was little affected. Urea was applied to the experimental paddocks on August 13, 1970, as half splits in two directions. Ground inspection indicated a satisfactory spread. Conditions during application were cool, with intermittent showers. The soil was very wet, and overnight showers followed; $8 \mathrm{~mm}$ of rain was recorded at "Ratahiwi" homestead for the $24 \mathrm{~h}$ to 0730 , August 14. 


\section{Pasture Production M EASUREM ENTS}

Regrowth was measured under cage exclosures. Four cages (each $2 \mathrm{~m}$ ") were used in each paddock. Cages were apportioned to representative site classes, although they were located at random within those areas. Site classes were defined according to 8 compass points for aspect, with three slope classes, flat, rolling and steep.

Following each measurement, cages were relocated at random on to pasture which had been grazed to that time, but within the site classes to which the particular cages had been allocated. Any clumpy, uneaten herbage was removed by pretrimming the fresh sites at the harvesting height.

As an adjunct to this study, continually mown, ungrazed plots were established within the control paddock of each block. Two cages were situated within each of the six control areas, on representative site classes. Urea to give $58 \mathrm{~kg} \mathrm{~N} / \mathrm{ha}$ was applied to one half of each (plot area $1 \mathrm{~m}^{2}$ ), while the other half received no fertilizer. Regrowth on these plots was measured at the same time, and in the same manner, as was that from other cages in the grazed area, but the cages were repositioned in the same place after each defoliation. In this way, the two fertilizer treatments were also compared under continual mechanical defoliation.

All cages were positioned, and fertilizer plots laid down, during the week following the aerial application of urea. Regrowth under all cages was measured three times over the ensuing three months, on September 22-24, October 20-22 and November 16-20, 1970. Samples were harvested from beneath the cages with an electric shearing handpiece, to leave a stubble approximating that in the grazed areas. At the first two measurements, this meant harvesting below $1 \mathrm{~cm}$. Herbage yields and species' contributions to yield were determined in the conventional manner. All cages were individually identified, and separate yield data were collected from each.

For statistical treatment of the data, the four values obtained at each harvest from each grazed paddock were averaged, giving six sets of data for comparison. Similarly, the two sets of values within control paddocks, from the.sites subject to repeated mechanical harvesting, were averaged, giving six sets of data for comparison. The data were statistically analysed as a $2 \times 2$ factorial, with six replications, comparing Control and Nitrogen treatmentts ("fertilizer" effect) and regrowth following grazing and mechanical harvesting ("defoliation" effect). In text and tables, the term "mown" is used to indicate the treatments where cages 
were relocated in the same place following each harvest. Individual identification of cages allowed yield comparisons between fertilizer treatments within site classes.

\section{Animal Measurements}

Animal measurements were considered to be a most relevant check on pasture measurements. Ewe and lamb liveweights were selected as the two characteristics for measurement. Accordingly, 25 ewes in each group were weighed and identified on August 17-18. These sheep were reweighed on December 9-10, three weeks after conclusion of pasture measurements. Test animals remained within the constraints of the experimental design until the final weighing. Any ewes not rearing lambs or late-lambing ewes were replaced in the experimental paddocks, with ewes and lambs, as the study progressed.

All ewes at the final weighing were known to have reared lambs, although a few of the test animals had been lost from some mobs (failure to rear lambs and occasional loss of eartags). At the final weighing, a random sample of 25 lambs from each mob were also weighed.

For statistical purposes, the individual weights within each group were averaged, giving six sets of data for comparison. Individual sheep were not identified.

\section{Meteorological Recordings}

Daily rainfall was recorded at "Ratahiwi" homestead. Monthly rainfall over the experimental period is presented in Table 2, together with monthly averages covering the period 1957-1974.

TABLE 2: METEOROLOGICAL RECORDINGS OVER THE EXPERIMENTAL PERIOD, AUGUST-NOVEMBER, 1970

\begin{tabular}{|c|c|c|c|c|c|c|}
\hline & \multicolumn{2}{|c|}{$\begin{array}{l}\text { Monthly Rainfall' } \\
(\mathrm{mm})\end{array}$} & \multicolumn{3}{|c|}{$\begin{array}{r}\text { Monthly Screen } \\
\left({ }^{\circ} \mathrm{C}\right)\end{array}$} & Temperaturesf \\
\hline & Recorded & $A v$. & $\operatorname{Max}$. & Min. & Mean & from Normal \\
\hline$\overline{\text { Aug. }}$ & 107.4 & 118.9 & 13.0 & 4.4 & 8.7 & +0.8 \\
\hline Sep. & 183.1 & 108.4 & 14.6 & 7.1 & 10.8 & +0.9 \\
\hline Oct. & 143.3 & 121.9 & 16.1 & 8.9 & 12.5 & +0.7 \\
\hline Nov. & 70.9 & 96.5 & 18.9 & 9.2 & 14.0 & +0.3 \\
\hline
\end{tabular}

* Recorded at farm homestead.

† Recordings by H. G. Cullen, Mangamutu, Pahiatua.

Source: N.Z. Gazette, 1970, extracted by N.Z. Meteorological Service. 
Temperature data reported in Table 2 are from an official station at Mangamutu, near Pahiatua, approximately $20 \mathrm{~km}$ from the property. It is considered that the monthly temperature deviations recorded there should be similar to those at the trial site.

\section{RESULTS}

Herbage yields are summarized in Table 3. Data for two minor botanical components, weed species and dead herbage, have not been presented. Together, they contributed some 6 to $7 \%$ of measured yield over the experimental period, irrespective of treatments.

The principal feature of results from the individual measurements was a significant fertilizer response on all three occasions.

TABLE 3: HERBAGE YIELDS MEASURED FOLLOWING THREE PERIODS OF REGROWTH, AND TOTALS FOR THE STUDY PERIOD AUGUST 20-NOVEMBER 18, 1970

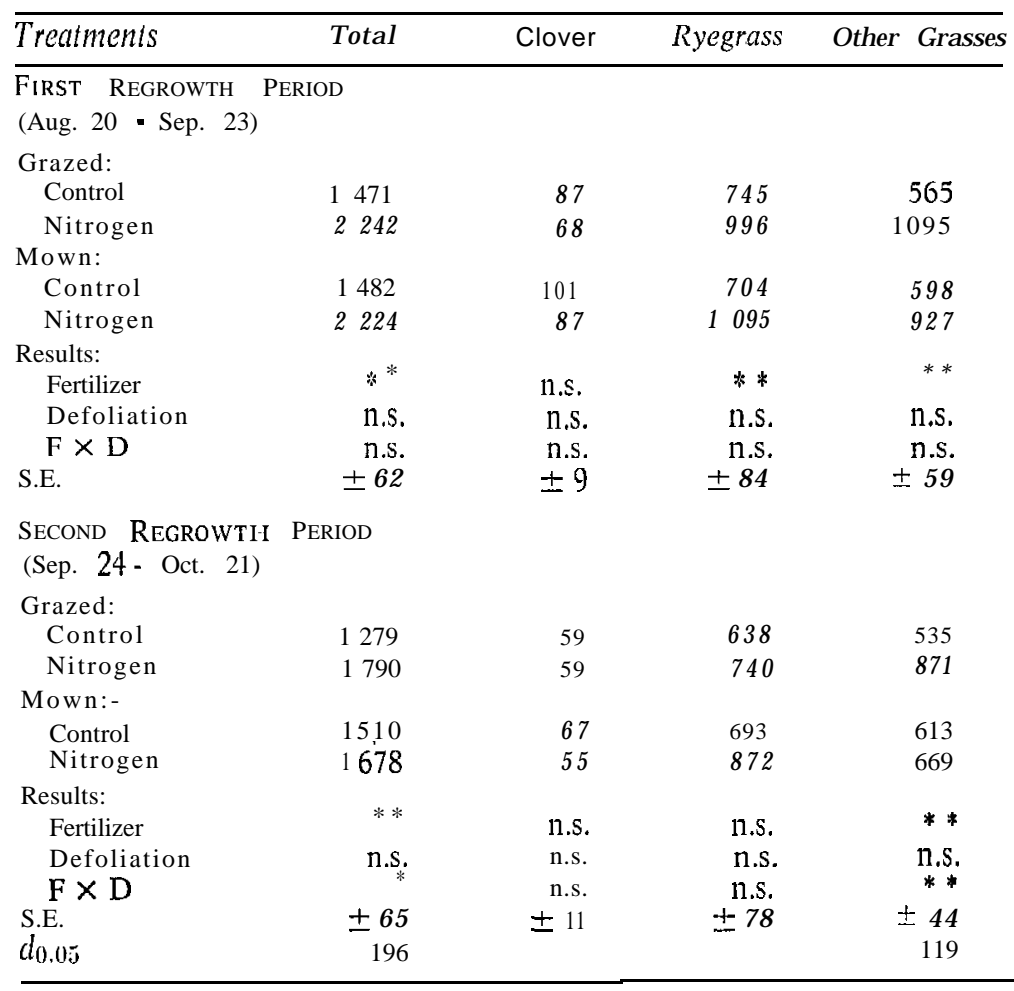


TABLE 4: MEAN TOTAL HERBAGE YIELDS FROM VARIOUS SITE CLASSES

\begin{tabular}{|c|c|c|c|c|c|c|c|}
\hline \multirow[b]{2}{*}{$\begin{array}{l}\text { Site } \\
\text { Class }\end{array}$} & \multicolumn{2}{|c|}{ Control } & \multicolumn{2}{|c|}{ Nitrogen } & \multicolumn{3}{|c|}{ A ver age responses } \\
\hline & $\begin{array}{l}\text { M ean Y ield } \\
(k \mathrm{~g} D M / h a)\end{array}$ & $\begin{array}{l}\text { No. of } \\
\text { Sites }\end{array}$ & $\begin{array}{l}M \text { ean Y ield } \\
(k g D M / h a)\end{array}$ & $\begin{array}{l}\text { No. of } \\
\text { Sites }\end{array}$ & $\mathrm{kg} D M / h a$ & $\%$ & $\begin{array}{c}\text { Efficiency } \\
\text { ( k g DM } / \mathrm{kg}\end{array}$ \\
\hline Flat to undulating & 5976 & 7 & 7363 & 8 & 1387 & 23 & 23.9 \\
\hline Rolling, N. aspect & 4902 & 4 & 6299 & 2 & 1397 & 29 & 24.1 \\
\hline Rolling, E. aspect & 5022 & 1 & 6674 & 1 & 1652 & & \\
\hline Rolling, SW. aspect & 5892 & 2 & 6353 & 5 & 462 & 38 & 28:19 \\
\hline Rolling, W. aspect & 4512 & 3 & 6256 & 4 & 1744 & 22 & $\begin{array}{l}20.1 \\
20.8\end{array}$ \\
\hline $\begin{array}{l}\text { Rolling, NW. aspect } \\
\text { Steep, NW. aspect }\end{array}$ & 5223 & 8 & 6427 & 7 & 1204 & & \\
\hline Steep, NW. aspect & 4199 & 2 & 6394 & 3 & 2195 & 52 & 37.8 \\
\hline A verage all site classes & 5103 & 27 & 6539 & 30 & 1436 & 28 & 24.8 \\
\hline
\end{tabular}


TABLE 3-contd.

\begin{tabular}{|c|c|c|c|c|}
\hline Treatments & Total & Clover & $R$ yegrass & Other-Grasses \\
\hline \multicolumn{5}{|c|}{$\begin{array}{l}\text { Third Regrowth P eriod } \\
\text { (Oct. } 22 \text {-Nov. 18) }\end{array}$} \\
\hline \multicolumn{5}{|l|}{ Grazed: } \\
\hline Control & 2327 & 118 & 978 & 1020 \\
\hline Nitrogen & 2861 & 75 & 1266 & 1271 \\
\hline \multicolumn{5}{|l|}{ Mown: } \\
\hline Control & 2185 & 93 & 898 & 1041 \\
\hline Nitrogen & 2072 & 69 & 931 & 925 \\
\hline \multicolumn{5}{|l|}{ Results: } \\
\hline Fertilizer & ${ }^{*}$ & n.s. & $n . s$ & n.s. \\
\hline Defoliation & $\begin{array}{l}* * \\
* *\end{array}$ & n.s. & n.s. & $*$ \\
\hline$F \times D$ & $* *$ & n.s. & n.s. & $* *$ \\
\hline $\begin{array}{l}\text { S.E. } \\
d_{0.05}\end{array}$ & $\begin{array}{r} \pm 93 \\
279\end{array}$ & \pm 14 & \pm 106 & $\begin{array}{r} \pm 59 \\
179\end{array}$ \\
\hline \multicolumn{5}{|c|}{$\begin{array}{l}\text { Totals For S tudy Period } \\
(\text { Aug. } 20 \cdot \text { Nov. } 18)\end{array}$} \\
\hline \multicolumn{5}{|l|}{ Grazed: } \\
\hline Control & 5076 & 264 & 2362 & 2120 \\
\hline Nitrogen & 6894 & 202 & 3003 & 3238 \\
\hline \multicolumn{5}{|l|}{ Mown: } \\
\hline Control & 5178 & 261 & 2295 & 2253 \\
\hline Nitrogen & 5973 & 211 & 2896 & 2521 \\
\hline \multicolumn{5}{|l|}{ Results: } \\
\hline Fertilizer & 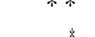 & n.s. & w & ** \\
\hline Defoliation & " & n.s. & n.s. & $* *$ \\
\hline $\mathrm{F} \times \mathrm{D}$ & $* *$ & n.s. & n.s. & \\
\hline $\begin{array}{l}\text { S.E. } \\
d_{0.05}\end{array}$ & $\begin{array}{r} \pm 165 \\
500\end{array}$ & \pm 27 & \pm 250 & $\begin{array}{r} \pm 93 \\
.314\end{array}$ \\
\hline
\end{tabular}

Ryegrass and "other grasses" both contributed to this at first, but thereafter ryegrass showed no significant response. Clover yields were unaffected throughout. Significant fertilizer $\times$ defoliation interactions occurred later. By the final measurement $\mathrm{N}$ responses were recorded for both total and "other grasses" yields in the grazed areas, but not where the plots had been repeatedly mown.

Over the three-month study period, total herbage production from the Nitrogen treatment was greater than from the Control, irrespective of the method of defoliation. In the grazed paddocks, measured herbage yield increased by $1820 \mathrm{~kg} \mathrm{DM} / \mathrm{ha}$, or $36 \%$. Where plots were continually mown, the measured $\mathrm{N}$ response was less than half this, $795 \mathrm{~kg} \mathrm{DM} / \mathrm{ha}$ or $15 \%$. Clover yields, while some $20 \%$ lower in the Nitrogen treatment, were not significantly 
TABLE 5: CLASSES OF STOCK, AND MEAN LIVEWEIGHTS FOR EWES AND LAMBS

\begin{tabular}{|c|c|c|c|c|c|c|}
\hline & $\begin{array}{l}\text { Blocks and } \\
\text { Treatments }\end{array}$ & Stock Class & \multicolumn{3}{|c|}{ Ewe Liveweights $(\mathrm{kg})$} & $\begin{array}{c}\text { Lamb Live } \\
\text { wgights }\end{array}$ \\
\hline 1 & $\begin{array}{l}\text { Control } \\
\text { Nitrogen }\end{array}$ & Cheviot X Romney 2-ths & 44.9 & 46.1 & $\begin{array}{l}+1.2 \\
+3.4\end{array}$ & $\begin{array}{l}18.2 \\
19.9\end{array}$ \\
\hline II & Geptrgedn & Romney X Perendale 4-th to $4^{y r}$ & $48: 1$ & 48.5 & $=0: 6$ & 29.2 \\
\hline III & Control & Romney 2-ths & 40.8 & 45.0 & +4.2 & 19.0 \\
\hline $\begin{array}{l}\text { IV } \\
\text { V }\end{array}$ & $\begin{array}{l}\text { Nitrogen } \\
\text { Control } \\
\text { dithrtegen }\end{array}$ & $\begin{array}{l}\text { Romney 4-th to } 4 \mathrm{yr} \\
\text { Romney 4-th to } 4\end{array}$ & $\begin{array}{l}40.5 \\
49.3 \\
46: 7\end{array}$ & $\begin{array}{l}46.6 \\
42.9 \\
42.6\end{array}$ & $\begin{array}{l}+6.1 \\
-6.4 \\
+2.4\end{array}$ & $\begin{array}{l}18.9 \\
17.3 \\
18.8\end{array}$ \\
\hline & Nitrogen & yr & 48.2 & 52.8 & +4.6 & $22: \%$ \\
\hline VI & Control & Romney 4-th to $4 \mathrm{yr}$ & 50.6 & 50.5 & +0.1 & 22.8 \\
\hline $\mathrm{Mec}$ & $\underset{n s}{\text { Nitrogen }}$ & & 47.6 & 50.2 & +2.6 & 22.8 \\
\hline & $\begin{array}{l}\text { Control } \\
\text { Nitrogen } \\
\text { Result }\end{array}$ & & 47.50 & $\begin{array}{l}47.47 \\
47.45 \\
\text { n.s. }\end{array}$ & $\begin{array}{l}+0.02 \\
+1.50\end{array}$ & $\begin{array}{c}20.10 \\
20.50 \\
\text { n.s. }\end{array}$ \\
\hline & S.E. & & \pm 0.35 & \pm 0.38 & \pm 0.35 & \pm 0.23 \\
\hline
\end{tabular}


affected. Under the conditions of the experiment, clovers (almost all Trifolium repens) were a minor botanical component, contributing only $5 \%$ to total yield from the Control pasture. Ryegrass yields increased with Nitrogen over the study period, by $620 \mathrm{~kg}$ $\mathrm{DM} / \mathrm{ha}$, or $25 \%$, irrespective of defoliation treatment. The yield of grasses other than ryegrass was also increased by the Nitrogen treatment; however, this effect was much more pronounced where regrowth was measured in the paddocks which had been continually grazed throughout the experiment. In the latter case, yield increased by $1120 \mathrm{~kg} \mathrm{DM} / \mathrm{ha}$, or $53 \%$, while in the mown plots the response was only $270 \mathrm{~kg} / \mathrm{ha}$, or $12 \%$, which was not significant. In both defoliation treatments, the yield of grasses other than ryegrass from the Control treatment was similar, when totalled over the study period.

Of the grasses, only ryegrass was separated during botanical analyses. However, the species making major contributions to "other grasses" were noted visually for each sample during dissection. Throughout the experiment, browntop (A grostis tenuis) and sweet vernal (Anthoxanthum odoratum) were the main constituents, each being the major contributor to $29 \%$ of samples. Poa (Poa spp.) and crested dogstail (Cynosurus cristatus) were 'intermediate, being pre-eminent species in 20 and $13 \%$ of samples, respectively, while Yorkshire fog (Holcus lanatus) and bromus mollis (Bromus mollis) were the principal contributors on 5 and $3 \%$ of occasions. Minor contributors included Poa pratensis and cocksfoot (D actylis glomerata). The frequency with which browntop was a major contributor was little affected by treatments, but its significance declined with time, from $40 \%$ of samples after the first regrowth period in late winter-early spring, down to $22 \%$ after the third regrowth period in late spring. The main compensatory change was in the frequency of crested dogstail. While a major contributor to only $6 \%$ of samples at the first measurement, this increased to $27 \%$ at the final measurement, when its frequency exceeded that of all other relevant species. Crested dogstail appeared to have been favoured by continual mowing, being the major contributor to $24 \%$ of samples from this defoliation treatment, but only $7 \%$ from the grazed series. The reverse was the case with sweet vernal (and poa) being the major contributors in $34(20 \%)$ of samples in the grazed and $25(12 \%)$ in the mown series, respectively. Poa was the species most affected by the fertilizer treatment. In one-quarter of the samples from the Nitrogen series, poa was the major contributor, but in only one-eighth of samples from the Control series. 
Mean total yields from the various site classes are reported in Table 4. Results are included only from those site classes on-which measurements of both fertilizer treatments were made. Average total yields over the three months are presented, including data from both grazed and mown sites, While there was a considerable range in average responses, a response to $\mathrm{N}$ is apparent, irrespective of slope or aspect. Response efficiency ranged from 8 to $38 \mathrm{~kg}$ $\mathrm{DM} / \mathrm{kg} \mathrm{N}$ applied. The average response over all site classes represented was $1436 \mathrm{~kg} \mathrm{DM} / \mathrm{ha}$, or $28 \%$, with an average response efficiency of $25 \mathrm{~kg} \mathrm{DM} / \mathrm{kg} \mathrm{N}$ applied.

Mean liveweights for ewes and lambs are presented in Table 5. Initial weighing took place just before lambing, a time when liveweights should have been near a peak value for the year (Suckling, 1954). There were significant differences among blocks in bodyweight changes. However, on average, ewes in the Nitrogen treatment gained significantly more body weight $(1.5 \mathrm{~kg})$ than those in the Control group $(0.02 \mathrm{~kg})$. Lamb weights did not differ significantly. The higher lamb body weights recorded in blocks $\mathrm{V}$ and VI were significant, and associated with the use of Down rams over the ewes in those mobs only.

No other aspect of stock performance was recorded. However, field observations indicated no difference between treatments in lambing performance, or in general stock health.

\section{Pasture Production}

(see Tables 3 and 4)

The response of $1820 \mathrm{~kg}$ / ha recorded over the experimental period in the grazed paddocks represents a response efficiency of $31.3 \mathrm{~kg} \mathrm{DM} / \mathrm{kg} \mathrm{N}$ applied. This compares very favourably with values of 10 to 20 , reported by During (1972), for dressings up to $34 \mathrm{~kg} \mathrm{~N} / \mathrm{ha}$ in the Taranaki-Manawatu region, and agrees more closely with values of 33 and 21 reported by Sherlock and O'Connor (1973) from Te Kuiti, for $\mathrm{N}$ rates of 25 and $50 \mathrm{~kg} / \mathrm{ha}$, respectively. As in their study, this experiment has shown that response efficiency increases with measurement of several consecutive regrowths to include residual responses. In the grazed treatment, the percentage response declined from an initial 52, through 40 , to 23 during the three consecutive measurements. The total yield response of $795 \mathrm{~kg}$ DM/ha measured in the mown plots, at a response efficiency of $13.7 \mathrm{~kg} \mathrm{DM} / \mathrm{kg} \mathrm{N}$, is in closer agreement with the values reported by During, and figures of 12 to 25 reported by Ball $(1970 \mathrm{~b})$ from the Manawatu. 
An unexpected feature of these results was the responsiveness to $\mathrm{N}$ of grasses other than ryegrass. At the first measurement, this sward component showed a greater response than ryegrass, which constituted $50 \%$ of the Control yield. Under continued grazing, the responsiveness of "other grasses" was sustained through all measurements. A number of New Zealand publications have reported the necessity to select ryegrass-dominant pastures in order to obtain satisfactory N responses (During, 1967; Ball, 1969; Sherlock and O'Connor, 1973), thereby implying that other grass species will be considerably less responsive than ryegrass. It was not so under the conditions of this experiment. Neilson (1974) reported from field experience in the Taihape-Waimarino area that satisfactory responses to fertilizer $\mathrm{N}$ could be obtained from hill country pastures over the late winter-early spring period, even where such pastures contained less than $20 \%$ ryegrass. During (1972) subsequently reported that Poa annua and P. trivialis are responsive to $\mathrm{N}$ in winter.

An explanation for the different responses measured in the grazed paddocks, as opposed to the mown plots, is not altogether clear. At the first measurement, there was very little between the two sets of results. This was to be expected, as both defoliation treatments had been treated alike to that point, and is considered to validate the view that differences which developed subsequently were truly the result of the different methods of defoliation. Soil conditions were very wet, and serious poaching was noticed in some areas. It is possible that treading damage penalized regrowth from the grazed areas, although this would have been expected to affect both Control and Nitrogen treatments. If this explanation were acceptable, rather larger $\mathrm{N}$ responses might have been expected from the grazed areas under drier conditions.

Similar results were reported by Sherlock and O'Connor (1973) from a study by During, where small, repeatedly mown plots had been situated in cattle-grazed pastures, with and without fertilizer $\mathrm{N}$ application. The explanation they gave for the superiority of $\mathrm{N}$ responses in the grazed situation was that recycling of $\mathrm{N}$, through the weaner steers involved, gave a measurable, residual $\mathrm{N}$ response, absent when the herbage was mown and discarded over three measurement periods. This explanation seems appropriate to the data obtained from the final harvest in the present study, but by itself does not fit in with the fact that total yields for Control treatments were almost identical over the sudy period, irrespective of the method of defoliation. $\mathrm{N}$ recycling, to any substantial extent, would have been expected to increase grazed Control yield relative 
to mown Control. The possibility of alternative, interacting effects, such as poaching under grazing and depletion of other nutrients when mowings are discarded, cannot be overlooked. While there is room for conjecture over the reasons, the point can be simply made that, had this study been confined to mown plots, the data obtained could have been misleading in relation to pasture performance in the continuously grazed areas.

In the planning of this experiment, subjective decisions were involved in choosing representative site classes on which to position cages. There were misgivings about trying to measure pasture production from paddocks 9 to 11 ha in area, using only four small cages. The possibility of bias between treatments, in cage allocations to site classes, was recognized. As an independent check on the response data obtained from the factorial design, Control and Nitrogen treatments were compared within site classes, irrespective of the blocks from which the data were derived (Table 4). While only 57 of the total 72 measurement sites could be included, the averaged total yields (Control $=5103 \mathrm{~kg} / \mathrm{ha}$; Nitrogen $=6539$ ) were very similar to those from the factorial design (Control $=$ $5120 \mathrm{~kg} / \mathrm{ha}$; Nitrogen $=6$ 433). It is considered that unequal representation of measurement sites within site classes, and the absence of comparable treatments from a number of site classes, preclude further interpretation from these data.

\section{ANIMAI PERFORMANCE}

(see Table 5)

In neither treatment did ewes gain a great deal in liveweight, but, as the first weighing was just prior to lambing, some reduction in body weights might well have been anticipated over the ensuing 4 months (Suckling, 1954). The significantly greater gain recorded by ewes from the Nitrogen treatment is considered indicative of better nutrition within that treatment. Such a conclusion is in sympathy with the associated pasture production data.

When this study started in August, feed was very short in all paddocks. By the conclusion of measurements, feed surpluses were apparent under both treatments. Experimental considerations dictated that urea had to be applied to hard-grazed pastures, shortly after intensive mob-grazing. Ewes were set-stocked almost immediately. Such practice is not recommended because of poorer responses from very short stubble, and a delay between $\mathrm{N}$ application and pasture responses (Ball, 1970a). The increased stocking rate must have exerted a considerably greater grazing pressure 
relative to the Control treatment, over the initial two to three weeks, before pasture DM responses to urea were effective; Visual responses in the mown plots, where both treatments were adjacent, were not noticed until the third week, In effect, the design penalized the Nitrogen treatment, with urea relied upon to meet the feed requirements of the extra animals, but only after making up the leeway from increased grazing pressure over the first few weeks, when feed availability was severely limited. With appropriate management, particularly the spelling of paddocks following $\mathrm{N}$ application, farmers might anticipate better results than those obtained in this study.

That the initial liveweight of the marked sheep in the Nitrogen group was significantly lower, was a chance occurrence, but an unfortunate aspect of the experiment. The greater liveweight gain of this group simply brought it up to the same final weight as the Control group, which raises the question of whether both treatments were stocked at an intensity which simply allowed them to reach their potential body weights by early December. Suckling (1959) reported much higher average liveweights for various age classes of Romney ewes at Te Awa, than were found in this experiment (two-tooths, 48.2 vs $43.2 \mathrm{~kg}$; four-tooth to 4 years, 55.0 vs $48.6 \mathrm{~kg}$ ). This comparison indicates that the stocking rates involved were sufficiently high to allow any improvement in feed availability to be expressed in improved liveweights, irrespective of the small liveweight difference between the two groups at the start of the experiment.

As there was no difference in lamb weights, increased pasture growth appears to have compensated for the $10 \%$ increase in stoclcing rate associated with the Nitrogen treatment.

\section{GENERAL}

The 1970 spring was considered by local farmers to be "better than average", resulting in surplus feed almost a month earlier than anticipated (see Table 2). Such seasonal variation probably worked against obtaining a more clear-cut result. It has been reported from Ruakura that winter $\mathrm{N}$ responses are lower during "growthy" winters than when control pasture production is low (During, 1972), with fertilizer $\mathrm{N}$ ensuring relatively high pasture production in spite of seasonal variation between years. The clement spring encountered during the present study certainly resulted in lambs being fed much more adequately than was anticipated. 
The absence of published information in the field has encour-aged the writers to compile this report, in spite of its limitations, in the sincere hope that it may prove useful, and may stimulate further studies of benefit to hill country farming.

\section{ACKNOWLEDGEMENTS}

The authors gratefully acknowledge assistance from $\mathrm{T}$. V. Holland, Grasslands Division, DSIR, Palmerston North; Mrs H. I-I. Soundy (née Inglis), joint owner of "Ratahiwi"; B. T. Robertson, East Coast Farmers' Fertiliser Co.: staff of Fieldair Ltd., Dannevirke, and East Coast Farmers' Fertilizer Co., Napier.

\section{REFERENCES}

Ball, Roger, 1969. Proc. N.Z. Grassld A SS., 31:117-26. 1970a. Shcep/mg A . 1970: 11-9. Massey University.

1970b. Dairyfmg A 1970: 72-81. Massey University.

During, C., 1967. Fertilisers and Soils in New Zealand Farming. Govt. Printer, Wellington.

1972. Fertilisers and Soils in New Zealand Farming, 2nd ed. Govt. Printer, Wellington.

Neilson, B. A., 1973. N.Z. fert. J. (42): 10-1.

1974. Ibid. (43): 11-2.

Mauger, John, 1971. Ibid. (38): 9-11.

Sherlock, R. R.; O'Connor, M. B., 1973. Proc. N.Z. Grassld Ass., 35 (1): $52-62$.

Suckling, F. E. T., 1954. N.Z. /l. Sci. Tech., 36A (3): 237-73.

1959. N.Z. Jl. agric. Res., 2: 488-543. 